\title{
PENGEMBANGAN SERIOUS GAME BERBASIS INKUIRI TERBIMBING PADA POKOK BAHASAN KPK DAN FPB UNTUK SISWA KELAS 4 SEKOLAH DASAR
}

\author{
I.N. Sukajaya ${ }^{1}$, K.A.T Raharja ${ }^{2}$, N.M.S Mertasari ${ }^{3}$ \\ 1,2,3 Jurusan Matematika/Prodi Pendidikan Matematika, Universitas Pendidikan Ganesha \\ Singaraja, Indonesia
}

e-mail: nyoman.sukajaya@undiksha.ac.id ${ }^{1}$, raharjateguh23@gmail.com² ${ }^{2}$ simertasarinimade@yahoo.co.id ${ }^{3}$

\begin{abstract}
Abstrak
Penelitian ini bertujuan mengembangkan serious game materi KPK dan FPB kelas 4 Sekolah Dasar yang dinamai "Math Snake", bersifat single player game di mana pemain diarahkan memiliki kompetensi pengetahuan dan keterampilan menentukan KPK dan FPB dua bilangan melalui proses bermain. Pencapaian kompetensi diperoleh melalui implementasi metode inkuiri yang diintegrasikan ke dalam skenario permainan. Pemain yang berhasil menyelesaikan seluruh tantangan dalam game dikategorikan sebagai pemenang, pemain yang kehabisan nyawa atau waktu dalam game akan mengalami Game Over. Prosedur pengembangan game menerapkan model penelitian 4D namun hanya sampai tahap ketiga. Kelayakan game dinilai oleh seorang ahli media dan seorang ahli materi. Hasil penilaian ahli menunjukkan bahwa game sudah terkategori baik dan merekomendasikannya untuk digunakan. Uji coba terbatas dilakukan terhadap empat siswa Sekolah Dasar kelas 4 menunjukkan bahwa mereka termotivasi dan antusias dalam menggunakan Math Snake. Dari hasil tersebut dapat disimpulkan bahwa Math Snake dapat digunakan sebagai media pembelajaran yang motivatif dan menyenangkan.
\end{abstract}

Kata kunci: serious game, KPK, FPB, metode inkuiri.

This study aimed at developing a serious game for the last common multiple and greatest common factor of $4^{\text {th }}$ grade students of elementary school. This game is called "Math Snake", that is a single player game where players are guided having the competence of knowledge and skills for determining the least common multiple and greatest common factor of two numbers through playing. Achievement of competencies is obtained through the implementation of the inquiry method that is integrated into the game scenario. The players who successfully complete all challenges in this game are stated as winners, but players who run out of lives or time are stated failed (Game Over). The author implemented the 4D model of game development which is practically conducted only until the third step. Games are rated by a media expert and a material expert. Expert is rating showed that game already has a good category and they recommend that Math Snake is suitable to be used as a learning media. A limited trial was conducted involving four students of the $4^{\text {th }}$ grade of elementary school. All children were motivated and enthusiastic in using Math Snake. Those results concluded that Math Snake can be used as a motivational and fun learning media.

Keywords : serious game, common multiple, greatest common factor, inquiry method.

\section{Diterima Redaksi: 15-01-2021 | Selesai Revisi: 05-03-2021 | Diterbitkan Online: 31-07-2021} DOI: https://doi.org/ 10.23887/janapati.v10i2.28137

\section{PENDAHULUAN}

Kini dunia telah memasuki era revolusi industri 4.0. Dalam era ini, teknologi informasi menjadi basis dalam segala kegiatan manusia termasuk dalam hal pendidikan. Pendidikan di era revolusi 4.0 menyebabkan berkembangnya proses pembelajaran. Untuk menghadapi perkembangannya, pendidikan harus dapat mencetak generasi yang kreatif, inovatif, serta kompetitif. $\mathrm{Di}$ era revolusi industri 4.0, pendidikan di Indonesia mulai memanfaatkan teknologi komputer dan internet dalam kegiatan pembelajaran [1]. Peningkatan kinerja pendidikan di masa mendatang diperlukan teknologi informasi dan komunikasi (TIK) yang tidak hanya berfungsi sebagai sarana pendukung, tetapi lebih sebagai senjata utama untuk mendukung keberhasilan dunia 
pendidikan sehingga mampu bersaing di pasar global (Haris)

Dalam kenyataannya di lapangan, pemanfaatan teknologi komputer masih belum maksimal. Berdasarkan pengamatan peneliti terhadap beberapa sekolah dasar, pada umumnya gutu telah menggunakan media pembelajaran berbasis TIK namun hanya berupa Power Point. Power Point hanya digunakan untuk memaparkan materi yang dibelajarkan oleh guru, sehingga siswa belum mendapatkan kesempatan untuk mengeksporasi pembelajaran sendiri menggunakan media pembelajaran Power Point. Oleh karena itu, diperlukan media pembelajaran yang diharapkan mampu memberikan kesempatan siswa untuk bereksplorasi pembelajaran dan menarik minat siswa untuk belajar matematika.

Dengan berkembangnya TIK, media pembelajaran lebih beragam. TIK memberikan fasilitas kepada guru dalam berinovasi sehingga membantu jalanya pembelajaran [2].Guru harus pintar memilih media yang tepat sehingga dapat mempermudahkan siswa memahami materi yang disampaikan, terutama untuk mata pelajaran yang bersifat abstrak dan dianggap kurang menarik bagi sebagian besar siswa, contohnya adalah mata pelajaran matematika. Banyak kendala-kendala yang menyebabkan siswa gagal dalam pembelajaran matematika. "Kendala tersebut berkisar pada karakteristik matematika yang abstrak, masalah media, masalah siswa atau guru" [3].

Guru hendaknya menciptakan pembelajaran yang mampu menumbuhkembangkan sikap apresiatif siswa, salah satunya adalah dengan menggunakan media pembelajaran yang menarik. Media pembelajaran adalah alat bantu pembelajaran yang digunakan untuk memperagakan fakta, konsep, prinsip atau prosedur tertentu agar terlihat lebih nyata [4]. Salah satu media pembelajaran berbasis TIK yang dapat digunakan oleh guru adalah media pembelajaran berbasis game.

Game adalah suatu permainan dengan aturan tertentu, untuk mencapai kemenangan [5]. Game berbasis teknologi dapat diartikan sebagai sebuah permainan yang diprogramkan kedalam suatu perangkat komputer. Sebuah game yang baik harus dirancang sesuai dengan kriteria game tersebut [6]. Kriteria dari game dengan konten pendidikan adalah sebagai berikut: (a) Kegunaan: Kemudahan dalam pengoprasian menjadi hal yang penting dalam sebuah game. Game yang dikembangkan menggunakan interface yang mudah dipahami oleh pemain dan menyediakan petunjukpetunjuk yang diperlukan dalam permainan; (b)
Keakuratan: Untuk mengajarkan pemain mengenai suatu keterampilan secara efektif, maka konten dari sebuah game harus akurat. Keakuratan dalam hal ini diartikan sebagai kesuksesan rancangan dan desain game diterapkan kedalam game. (c) Kesesuaian: Isi dan desain game harus dapat disesuaikan dengan kebutuhan pengguna. Game yang dikembangkan disesuaikan dengan kebutuhan pemain yaitu siswa dalam mempelajari materi tentang KPK dan FPB; (d) Relevan: Isi game harus dapat disampaikan ke pengguna. Sistem dalam game harus dapat menuntun pemain untuk mencapai tujuan yang diharapkan. (e) Objektivitas: Objektivitas juga merupakan bagian penting dalam suatu game, terutama game dengan konten pendidikan. Objektivitas menentukan tujuan pemain dan menentukan keberhasilan atau kegagalan. Dalam game pendidikan, tujuan terkait dengan hasil pembelajaran; (f) Umpan balik: Game sebaiknya menyediakan umpan balik untuk menyampaikan ke pengguna bahwa pemainan mereka sesuai game atau tidak. Umpan balik tersebut menandakan kegagalan atau kesuksesan yang dapat berupa efek suara atau animasi; (g) Daya Tarik: Game yang menarik mendorong pemain untuk terus bermain, dalam game dengan konten pendidikan berarti pemain merasa tertarik untuk belajar. Fitur yang baik di dalam game membuat pemain tertarik untuk bermain, seperti alur game, kejelasan mengenai aturan dan tujuan, kemudahan penggunaan, serta tampilan game. Selain itu, game yang baik harus menyediakan tantangan yang cukup untuk menjaga ketertarikan pemain. Artinya tantangan yang tidak terlalu mudah dan tidak terlalu sulit. Game yang terlalu mudah akan menimbulkan kebosanan, sedangkan game yang terlalu sulit akan menimbulkan frustasi dan tidak termotivasi untuk bermain; (h) Motivasi: Motivasi dapat diartikan sebagai faktor yang mendorong pemain untuk memainkan game. Strategi untuk memotivasi pemain dapat dilakukan dengan memberikan skor atau umpan balik, dan memberikan manfaat dari tantangan yang dipecahkan.

Saat ini game sudah mulai dikembangkan lebih dari sekedar hiburan contohnya adalah serious game. Serious game adalah game yang dibangun untuk tujuan non-entertainment tanpa menghilangkan fungsi hiburannya [7]. Inti dari pembelajaran berbasis game adalah sebagai pendukung dan penyedia pengalaman lingkungan belajar dalam membangun pengetahuan secara mandiri [8].

Banyak manfaat yang bisa diperoleh dengan mengimplementasikan serious game kedalam proses pembelajaran. Nuansa hiburan 
dan tantangan yang ada pada serious game mampu menarik perhatian dan meningkatkan motivasi siswa untuk belajar [9].Guru dapat menciptakan lingkungan belajar yang menyenangkan melalui serious game, sehingga berharap dapat membebaskan siswa dari berbagai tekanan psikologis. Dengan menggunakan serious game ke dalam proses pembelajaran, siswa diberikan kesempatan untuk belajar secara mandiri. Selain itu, pemanfaatan game dalam dunia pendidikan formal dan informal memiliki kesempatan untuk meningkatkan sistem pendidikan menjadi yang lebih baik [10].

Game yang dikembangkan membelajarkan materi Kelipatan Persekutuan Terkecil (KPK) dan Faktor Persekutuan Terbesar (FPB) sehingga garis besar, konsep permainan dalam Math Snake dibagi menjadi dua bagian. Bagian pertama membahas KPK, bagian kedua membahas FPB. Alur permainan disesuaikan dengan tahapan dalam membelajarkan KPK dan FPB. Skenario permainan pada bagian pertama yang disesuaikan dengan tahapan dalam membelajarkan KPK yaitu: a) menentukan kelipatan suatu bilangan, b) menentukan kelipatan persekutuan dari dua bilangan, c) menentukan kelipatan persekutuan terkecil dari dua bilangan. Skenario permainan bagian kedua disesuaikan dengan tahapan dalam membelajarkan FPB sebagai berikut: a) menentukan faktor suatu bilangan, b) menentukan faktor persekutuan dari dua bilangan, c) menentukan faktor persekutuan terbesar dari dua bilangan. Sistem menyediakan waktu 5 menit dan 5 nyawa untuk menyelesaikan satu bagian permainan. Permainan selesai (game over) ketika pemain kehabisan waktu atau nyawa ular telah habis.

Serious game yang dikembangkan dalam penelitian ini berbasis inkuiri terbimbing. Metode Inkuiri merupakan metode yang memberikan kesempatan siswa untuk melakukan eksperimen sendiri agar dapat melihat yang terjadi, melakukan sesuatu, mengajukan pertanyaan dan mencari jawaban secara mandiri, serta menghubungkan penemuanpenemuan yang telah diperoleh [11]. Metode inkuiri dilipih oleh peneliti untuk diaplikasikan dengan serious game karena metode ini memiliki beberapa keuntungan, seperti yang dijelaskan oleh Hanafiah dan Cucu Suhana [12] diantaranya adalah: a) pengetahuan yang didapat siswa diperoleh secara mandiri sehingga lebih dipahami, b) memberi kesempatan siswa untuk berkembang sesuai dengan kemampuannya, c) membantu siswa dalam mengembangkan keterampila dalam proses kognitif, dan d) kepercayaan diri siswa menjadi bertambah karena siswa menemukan sendiri pengetahuannya. Terdapat beberapa ciri-ciri metode inkuiri menurut sanjaya [13] seperti: a) kegiatan siswa dijadikan sebagai pusat pembelajaran, b) siswa aktif dalam mencari suatu jawaban, c) siswa dituntut untuk dapat menggunakan potensi dalam diri, seperti mengembangkan kemampuan berpikir logis, kritis, dan sistematis

Beberapa penelitian telah menunjukkan bahwa media pembelajaran berbasis game dapat digunakan sebagai media pembelajaran dikelas, diantaranya adalah penelitian oleh I Md. Suka Maryana [14] yang berjudul "Pengembangan Game Edukasi Sebagai Media Pembelajaran Deret Bilangan di Sekolah Menengah Atas" menyatakan bahwa multimedia pembelajaran yang dikembangkan memenuhi kriteria valid, praktis, dan efektif sehingga dapat diterima dan layak digunakan sebagai media pembelajaran pada materi deret tak hingga. Dalam penelitian I Nengah Adi Mahendra [15] yang berjudul "Pengembangan Multimedia Berbentuk Game Edukasi pada Sub Pokok Bahasan Refleksi dan Translasi di Sekolah Menengah Pertama" menyatakan bahwa game edukasi yang dikembangkan telah memenuhi kriteria valid, praktis dan efektif sehingga media pembelajaran ini layak untuk digunakan sebagai multimedia pembelajaran pada sub pokok bahasan refleksi dan translasi oleh siswa maupun guru.

Berdasarkan beberapa penelitian yang telah dipaparkan diatas, peneliti belum menemukan adanya kolaborasi antara metode pembelajaran dengan pembelajaran berbasis game. Sehingga tahapan-tahapan yang ada dalam game belum jelas sehingga belum bisa memfasilitasi tahapan berpikir siswa. Serious game yang dikembangkan dalam penelitian ini menggunakan metode inkuiri terbimbing. Metode inkuiri adalah metode yang memberikan kesempatan siswa untuk melakukan ujicoba secara mandiri agar dapat mengetahui apa yang terjadi, mengajukan pertanyaan, menghubungkan penemuan-penemuan yang telah diperoleh sehingga dapat menemukan jawaban dengan caranya sendiri.Game ini menekankan pada proses menyelidiki informasi untuk menyelesaikan tantangan. Game menyediakan petunjuk-petunjuk yang diperlukan dalam materi KPK dan FPB kepada pemain.

Berdasarkan hal tersebut, pada penelitian ini dibahas mengenai media pembelajaran berbasis serious game dalam pembelajaran matematika, yang berjudul "Pengembangan Serious Game berbasis Inkuiri Terbimbing pada Pokok Bahasan KPK dan FPB untuk Siswa Kelas 4 Sekolah Dasar". Penelitian ini 
bertujuan untuk menghasilkan rancangan serious game berbasis inkuiri terbimbing pada pokok bahasan KPK dan FPB untuk siswa Sekolah Dasar kelas 4, serta mengetahui rekomendasi ahli dan penerimaan pengguna terhadap serious game yang dikembangkan.

\section{METODE}

Penelitian ini dilakukan dengan pendekatan penelitian dan pengembangan (research and development). Research and development dilakukan untuk menghasilkan suatu produk dan menguji kualitas produk tersebut [16] . Berdasarkan pengertian tersebut, penelitian ini bertujuan untuk menghasilkan produk berupa serious game untuk pembelajaran. Adapun model penelitian yang digunakan adalah model penelitian dan pengembangan Four $D$ (4D). Tahapan pengembangan model 4D terdiri dari empat tahapan yaitu tahap pendefinisian (define), perancangan (design), pengembangan (develop) dan penyebaran (disseminate). Namun karena keterbatasan waktu, biaya, dan kemampuan dari peneliti, penelitian ini hanya dilakukan sampai tahap pengembangan (develop).

Pada tahap define peneliti melakukan obsevasi mengenai materi dalam mata pelajaran matematika yang dirasa tepat jika dibelajarkan dengan game, dan diperoleh materi KPK dan FPB. Selain itu pada tahapan ini dilakukan kegiatan analisis kurukulum dan deskripsi materi ajar untuk siswa kelas 4 semester genap. Materi yang ada pada game akan dievaluasi oleh ahli materi melalui penilaian terhadap prototype I (produk awal) serious game yang dikembangkan.

Selanjutnya pada tahap design dilakukan dengan 3 kegiatan utama, yaitu: 1) membuat skenario game, 2) membuat interface game, 3) membuat rancangan awal (Prototype I) serious game. Tahap terakhir adalah tahap development. Pada tahap ini, prototype I serious game dinilai oleh ahli berdasarkan angket yang telah disediakan. Tahapan ini meliputi penilaian serious game dari segi tampilan yang dilakukan oleh ahli media dan penilaian serious game dari segi materi yang dilakukan oleh ahli materi. Hal ini bertujuan untuk mengetahui bagaimana rekomendasi ahli terhadap serious game yang dikembangkan Selain itu, para ahli memberikan komentar, saran, dan masukan-masukan perbaikan game. Dalam tahap revisi, kekurangan dan kelemahan itu diperbaiki. Perbaikan produk dilakukan dengan memperhatikan rekomendasi dan saran dari para ahli, sehingga diperoleh prototype final serious game yang siap diujicobakan.
Instrumen yang digunakan dalam penelitian ini berupa angket (kuisioner). Angket digunakan untuk mengumpulkan data penilaian para ahli terhadap serious game. Penelitian ini menggunakan 2 jenis angket, yaitu angket penilaian dari ahli materi dan agket penilaian dari ahli media. Angket dibuat berdasarkan LORI (Learning Objek Review Instrument) yang dikembangkan Nesbit et al [17] . LORI merupakan instrumen penilaian yang biasanya digunakan untuk menilai suatu media pembelajaran. beberapa aspek-aspek yang terdapat dalam LORI diantaranya: kualitas isi/materi, pembelajaran, umpan balik dan adaptasi, motivasi, desain presentasi, kemudahan penggunaan, dan aksebilitas Berikut aspek yang digunakan dalam penilaian kelayakan media pembelajaran oleh ahli materi.

Penelitian ini menggunakan teknik analisis data kualitatif. Teknik analisis kualitatif digunakan untuk mendeskripsikan respon pengguna saat memainkan game berdasarkan pengamatan peneliti, sedangkan rekomendasi pengguna dideskripsikan berdasarkan hasil penilaian yang dicocokkan dengan kriteria penilaian ahli. Kriteria penilaian ahli menurut Widoyoko [18] diperoleh dengan cara: 1) Hitung simpangan baku ideal $\left(s b_{i}\right)$ dan rata-rata skor ideal $\left(\bar{X}_{i}\right)$ berdasarkan data penilaian dari ahli; 2) Konversi skor aktual atau total skor dari ahli $(X)$ menjadi nilai kualitatif skala lima berdasarkan tabel 1 sehingga diperoleh tabel 2 mengenai kriteria penilaian ahli media, dan tabel 3 mengenai kriteria penilaian ahli materi. Serious game yang dikembangkan dapat dikatakan "direkomendasikan oleh ahli" apabila kriteria minimal yang dicapai adalah "baik".

\section{HASIL DAN PEMBAHASAN}

Penelitian ini menghasilkan produk serious game dengan judul "Math Snake", sebuah game berbasis Personal Computer (PC) yang dibuat dengan menggunakan aplikasi Constuct 2. Game ini dimainkan oleh satu orang (single player). Game ini merupakan media pembelajaran matematika khususnya materi KPK dan FPB pada kelas 4 Sekolah Dasar yang berbasis inkuiri terbimbing. Skenario permainan Math Snake terdiri dari 2 bagian. Bagian pertama tentang tahapan-tahapan dalam membelajarkan KPK, dan bagian kedua tentang tahapan-tahapan dalam membelajarkan FPB.

Game ini menggambarkan seekor ular yang sedang mencari makanan. Pemain mengontrol laju ular sehingga dapat mencari makanan dan menghindari rintangan. Makanan yang digunakan dalam Math Snake berupa angka-angka yang sesuai dengan jawaban dari 
pertanyaan pada sistem. Makanan muncul dengan posisi yang acak.

Tabel 1. Konversi Skor Penilaian Ahli

\begin{tabular}{cl}
\hline Interval & \multicolumn{1}{c}{ Kriteria } \\
\hline$X>\left(\bar{X}_{i}+1,8 s b_{i}\right)$ & Sangat Baik \\
$\left(\bar{X}_{i}+0,6 s b_{i}\right)<X \leq\left(\bar{X}_{i}+1,8 s b_{i}\right)$ & Baik \\
$\left(\bar{X}_{i}-0,6 s b_{i}\right)<X \leq\left(\bar{X}_{i}+0,6 s b_{i}\right)$ & Cukup Baik \\
$\left(\bar{X}_{i}-1,8 s b_{i}\right)<X \leq\left(\bar{X}_{i}-0,6 s b_{i}\right)$ & Kurang Baik \\
$X \leq\left(\bar{X}_{i}-1,8 s b_{i}\right)$ & Tidak Baik \\
\hline
\end{tabular}

Tabel 2. Kriteria Penilaian Ahli Media

\begin{tabular}{cl}
\hline \multicolumn{1}{c}{ Interval } & \multicolumn{1}{c}{ Kriteria } \\
\hline$X>(25,5)$ & Sangat Baik \\
$(20,4)<X \leq(25,5)$ & Baik \\
$(15,6)<X \leq(20,4)$ & Cukup Baik \\
$(10,8)<X \leq(15,6)$ & Kurang Baik \\
$X \leq(10,8)$ & Tidak Baik \\
\hline
\end{tabular}

Tabel 3. Penilaian Ahli Materi

\begin{tabular}{cl}
\hline Interval & \multicolumn{1}{c}{ Kriteria } \\
\hline$X>(42,006)$ & Sangat Baik \\
$(34,002)<X \leq(42,006)$ & Baik \\
$(25,998)<X \leq(34,002)$ & Cukup Baik \\
$(17,994)<X \leq(25,998)$ & Kurang Baik \\
$X \leq(17,994)$ & Tidak Baik \\
\hline
\end{tabular}

Skor bertambah satu dan ular bertambah panjang ketika berhasil memangsa makanan. Angka-angka yang tidak sesuai jawaban menjadi rintangan dalam game ini. Saat ular memangsa angka yang salah, nyawa ular berkurang satu. Game over terjadi apabila waktu atau nyawa ular habis. Saat memulai game, sistem memperlihatkan tampilan awal game seperti pada gambar 1 .

Tampilan awal terdiri dari tombol tentang game, main, dan keluar. Tombol tentang game digunakan untuk masuk ke bagian informasi game. Informasi yang disampaikan berupa fungsi game, cerita game, materi pembelajaran yang digunakan, pengembang game, dan beberapa sumber asset dalam pembuatan game yang diambil dari internet. Guru yang baik adalah guru yang bisa memberi peunjuk kepada siswa kearah pencapaian jawaban yang benar [19]. Demikian juga game ini, saat memilih tombol main sistem akan mengarahkan pemain untuk menyimak petunjuk permainan atau tutorial game. Tutorial game bertujuan untuk melatih pemain mengenai cara bermain Math Snake, menyampaikan peraturan-peraturan yang berlaku pada game, dan memperkenalkan tampilan arena permainan kepada pemain. Dengan adanya tutorial game diharapkan dapat mempermudah pemain saat menggunakan game.

Terdapat 2 tombol pada tampilan tutorial, yaitu tombol SELANJUTNYA dan tombol SEBELUMNYA. Tombol selanjutnya digunakan untuk melihat tutorial selanjutnya. Terdapat 4 petunjuk pada tampilan tutorial dalam Math Snake. Game memberikan kesempatan pemain untuk melihat petunjuk yang terlewat dengan memberikan tombol SEBELUMNYA. Terdapat tombol MAIN di akhir petunjuk Apabila pemain sudah paham dengan tutorial, maka pemain dapat memilih tombol MAIN untuk memulai game. 


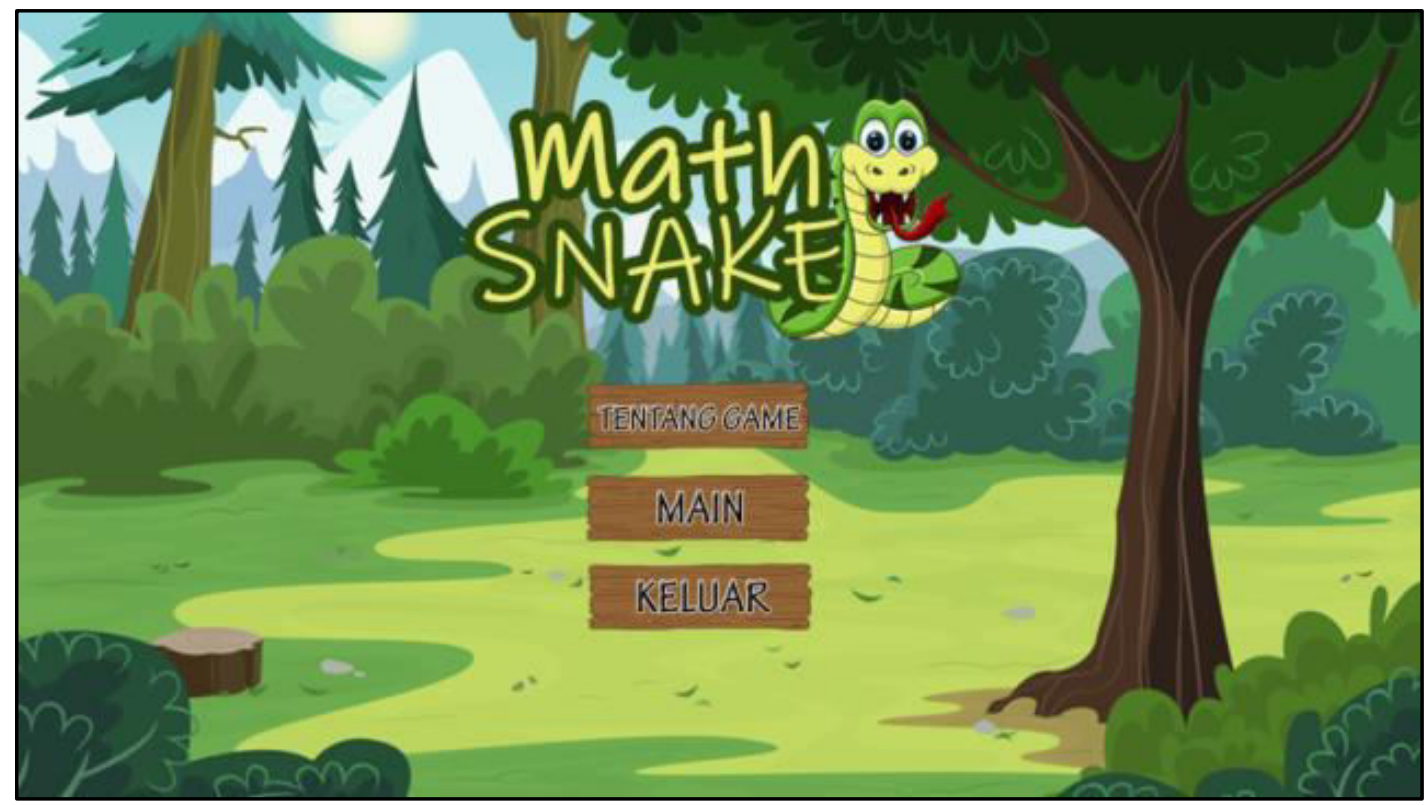

Gambar 1. Tampilan Awal Game

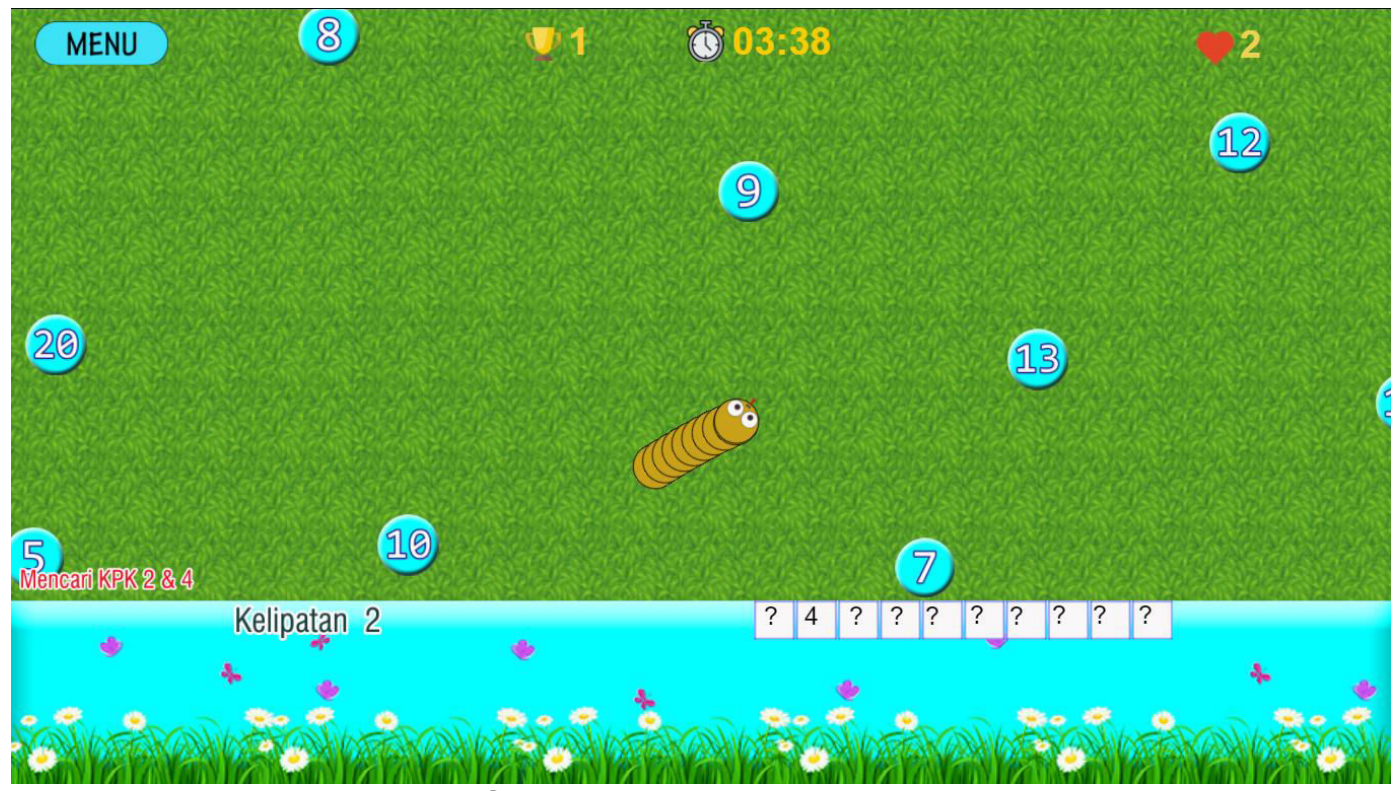

Gambar 2. Arena Permainan

Game dimulai dari bagian pertama yaitu bagian dalam pembelajaran KPK. Arena permainan dapat dilihat pada gambar 2. Arena tersebut bergeser secara horizontal dan vertikal mengikuti posisi ular. Pada tahapan ini digambarkan seekor ular di sebuah lapangan berumput yang sedang mencari makanan dan terdapat beberapa angka-angka di sekitar ular.

Disinilah tugas pemain untuk mementukan angka mana yang merupakan makanan ular dan bukan makanan ular. Topik yang dibahas pada tahapan ini sesuai dengan alur dalam membelajarkan KPK, yaitu menentukan kelipatan suatu bilangan, menentukan kelipatan persekutuan dari 2 bilangan, dan yang terakhir adalah menentukan KPK 2 bilangan yang telah diketahui kelipatan dan kelipatan persekutuannya. Pemain dapat menentukannya dengan memperhatikan pertanyaan yang muncul. Angka-angka jawaban dari pertanyaan merupakan makanan ular, sedangkan angka-angka bukan jawaban merupakan rintangan bagi ular.

Terdapat tombol MENU di pojok kiri atas layar pada tahapan ini. Tombol MENU berfungsi untuk mengarahkan pemain ke halaman menu (tampilan awal game). Selain itu, pada tampilan ini memperlihatkan waktu 5 menit dan 5 hati. Waktu berkurang saat permainan dimulai. Ketika waktu habis maka permainan selesai (game over). Lambang 5 hati menunjukkan 
bahwa ular memiliki 5 nyawa. Game over terjadi apabila nyawa ular habis.

Sistem memperlihatkan skor pemain dan 3 tombol saat game over, yaitu tombol PETUNJUK, tombol MAIN LAGI, dan tombol MENU. Tombol PETUNJUK dapat dipilih pemain apabila pemain ingin kembali melihat petunjuk permainan. Tombol ini mengarahkan pemain kembali ke tahapan tutorial. Apablia pemain ingin mengulangi game tanpa melalui tahapan tutorial, pemain dapat memilih tombol MAIN LAGI. Sistem akan mengulangi tahapan KPK dengan soal yang berbeda dari sebelumnya. Waktu dan nyawa dikembalikan seperti semula yaitu 5 menit dan 5 nyawa. Tombol MENU berfungsi untuk mengarahkan pemain ke tampilan awal game.

Apabila pemain berhasil menyelesaikan tahapan KPK, maka game akan berlanjut ke bagian kedua yaitu tahapan FPB. Topik yang dibahas pada tahapan ini sesuai dengan alur dalam membelajarkan FPB, yaitu menentukan fakor suatu bilangan, menentukan faktor persekutuan dua bilangan, dan yang terakhir adalah menentukan FPB 2 bilangan yang telah

diketahui faktor persekutuannya. Sama halnya dengan tampilan pada bagian KPK, pada bagian FPB juga diberikan waktu 5 menit dan 5 nyawa. Kondisi yang menyebabkan game over pada bagian FPB sama seperti pada bagian KPK, yaitu ketika waktu atau nyawa habis.

Skema permainan pada bagian FPB sama dengan bagian KPK. Pada tahapan faktor persekutuan, apabila ular memakan angka yang merupakan faktor persekutuan dari dua bilangan maka sistem akan memberikan warna merah pada masing masing bilangan yang bersekutu. Pemain berhasil menyelesaikan game apabila pemain mampu menyelesaikan tahapan FPB. Diakhir permainan akan disampaikan skor akhir pemain.

Untuk mengetahui bagaimana rekomendasi ahli, maka dilakukan penilaian terhadap prototype I serious game yang dikembangkan oleh para ahli. Ahli terdiri dari dua orang yaitu satu orang dosen Pendidikan Teknik Informatika yang dijadikan sebagai ahli media, dan satu orang dosen Pendidikan Matematika sebagai ahli materi. Para ahli melakukan penilaian terhadap prototype I serious game yang dikembangkan melalui angket penilaian kelayakan media pembelajaran.

Ahli media memberikan penilaian terhadap prototype I serious game yang dikembangkan dengan skor 24, setelah melalui proses perhitungan, dan disesuaikan dengan tabel 2 skor ini berada pada kategori "Baik" sehingga serious game yang dikembangkan direkomendasikan sebagai media pembelajaran. Selain memberikan penilaian, ahli materi juga memberikan tanggapan dan saran. Beliau memberikan tanggapan bahwa secara garis besar game dapat dimainkan dengan mudah, dan sudah diberikan navigasi yang cukup jelas. Beberapa saran beliau terhadap prototype I serious game yang dikembangkan adalah masih ada beberapa kesalahan penulisan di dalam game sehingga perlu diperbaiki, soal di game kurang bervariasi, dan dalam menu tentang game sebaiknya dicantumkan juga identitas pengembangnya, dan sumber asset jika mendapatkan dari internet (gambar dan musik). Namun secara keseluruhan game ini layak diuji cobakan ke pengguna.

Hasil penilaian dari ahli materi memberikan skor sebesar 49, berdasarkan tabel 3 skor ini berada pada kategori "Sangat Baik" sehingga berdasarkan penilaian ahli materi serious game yang dikembangkan direkomendasikan sebagai media pembelajaran matematika khususnya pada materi KPK dan FPK kelas 4 sekolah dasar. Selain memberikan penilaian, ahli materi memberikan komentar terhadap prototype I serious game yang dikembangkan agar dapat digunakan sebagai bahan pertimbangan untuk memperbaiki game. Ahli materi memberikan beberapa komentar diantaranya adalah posisi makanan ular terlalu jauh, sehingga pemain banyak kehabisan waktu dalam mencari makanan. Beliau menyarankan agar jarak antar makanan dipersempit. Selain itu beliau juga memberikan masukan agar animasi yang digunakan dibuat lebih menarik untuk anak SD.

Berdasarkan penilaian ahli materi dan ahli media, peneliti melakukan beberapa perbaikanperbaikan terhadap prototype I serious game yang dikembangkan. Perbaikan tersebut berguna untuk melengkapi kekurangankeurangan yang ditemukan saat dinilai oleh ahli materi dan ahli media. Setelah melalui proses perbaikan maka dihasilkan prototype final serious game.

Serious game yang dikembangkan diujicobakan terhadap 4 orang pemain yang merupakan siswa kelas 4 Sekolah Dasar. Saat membuka game ada pemain yang memilih tombol TENTANG GAME dan ada yang langsung memilih tombol MAIN. ketika memilih tombol MAIN, game sudah menyediakan aturan dan petunjuk permainan sehingga pemain tidak merasa kebingungan saat mulai memainkan Math Snake. Masuk ke arena permainan, awalnya beberapa pemain terlihat kesulitan dalam mengendalikan pergerakan ular. Namun tidak memerlukan waktu yang lama pemain mulai menguasai cara mengendalikan ular, baik 
untuk memakan mangsa maupun menghindari rintangan.

Bagian pertama dalam Math Snake adalah bagian KPK. Bagian ini terdiri dari 3 tahapan yaitu menentukan kelipatan suatu bilangan, menentukan kelipatan persekutuan dua bilangan, dan mentukan kelipatan persekutuan terkecil dua bilangan. Saat tahapan menentukan kelipatan persekutuan dua bilangan, pemain merasa terbantu karena ia telah mencari kelipatan dari kedua bilangan tersebut sehingga dalam menentukan KPK pemain hanya perlu memlilih bilangan terkecil pada kelipatan pesekutuan yang telah ditentukan. Pemain yang berhasil menyelesaikan bagian KPK akan dilajutkan ke bagian FPB. Tindakan pemain dalam memainkan bagian FPB sama seperti bagian KPK.

Berdasarkan pengamatan, para pemain terlihat sangat antusias dalam memainkan game. Keunggulan pembelajaran dengan menggunakan media berbasis komputer salah satunya adalah dapat menimbulkan motivasi bagi mereka untuk lebih menekuni materi yang disajikan [20]. Sejalan dengan hal tersebut, pemain sangat termotivasi dalam bermain game. Saat mereka gagal dalam suatu tahapan, mereka tidak ragu untuk memilih tombol MAIN LAGI. Mereka termotivasi untuk menyelesaikan semua tantangan yang ada dalam game dan berlomba-lomba untuk memperoleh skor tertinggi diantara satu anak dengan anak lainnya.

Menurut wawancara dengan salah satu orang tua anak, anaknya sangat takut dengan matapelajaran matematika. Anak tersbut menganggap bahwa matapelajaran matematika merupakan matapelajaran yang sulit. Dengan mindset ini, anak tidak akan mau belajar dan mencoba sebelum mengerjakan soal. Namun saat diberikan game ini, anak tersebut tampak sangat senang dan menikmati permainan, dan sama sekali tidak terlihat takut mencoba bahkan berani mengulang saat menemukan kegagalan. Rasa penasaran utuk menyelesaikan game mendorong anak tersebut untuk belajar dari kesalahan sebelumnya. Hal ini dapat menunjukkan bahwa serious game yang dikembangkan berkontribusi dalam meningkatkan minat belajar matematika siswa, dan mengubah mindset siswa mengenai mata pelajaran matematika yang dianggap sulit dan membosankan menjadi mudah dan menyenangkan.

Diterapkannya konsep inkuiri terbimbing kedalam game menjadikan penelitian ini dapat memberikan kontribusi lebih dibandingkan penelitian sebelumnya. Game ini dirancang sedemikian rupa sehingga mampu memfasilitasi siswa untuk mencari dan menemukan informasi sesuai dengan proses kognitifnya masing masing. Belajar menggunakan game dapat memfasilitasi siswa sehingga mereke menjadi pusat pembelajaran. dalam hal ini, siwa sebagai pemain aktif dalam mencari jawaban suatu permasalahn yang dimunculkan dalam game. Pemain dituntut untuk dapat menggunakan potensi didalam dirinya, seperti kemampuan berpikir logis, kritis dan sistematis.Sesuai pengamatan saat melakukan ujicoba terbatas terhadap beberapa anak, terlihat ketika beberapa pemain mempunyai cara yang berbeda saat menentukan kelipatan suatu bilangan. Contohnya saat menentukan kelipatan 3. Ada pemain yang mengurutkan bilangan kelipatan 3 dari bilangan terkecil sampai bilangan terbesar. Pemain lain yang memiliki pemahaman lebih baik tentang kelipatan, menentukan kelipatan 3 dilakukan secara acak. Menentukan kelipatan secara berurutan memerlukan waktu lebih lama dibandingkan dengan menentukan secara acak sehingga sisa waktu pemain untuk menyelesaikan tahapan berikutnya menjadi lebih sedikit. Disinilah sangat penting kemampuan dalam berlogika dan strategi yang dimiliki masing masing anak untuk menyelesaikan seluruh tantangan dalam game. Waktu sangat berperan penting dalam permainan ini. Sistem menyediakan waktu 5 menit dalam setiap tahapannya. Pembatasan waktu diberikan dengan alasan supaya pemain tidak terlalu lama memainkan game sehingga menimbulkan kejenuhan bermain, dalam hal ini juga berarti kejenuhan dalam belajar. Selain waktu, pemberian 3 nyawa di setiap bagian game dilakukan dengan alasan meminimalisir kemungkinan pemain untuk mencoba-coba jawaban, yang dalam game ini mencoba-coba memakan seluruh angka sebagai makanan. Dengan diberikan batasan nyawa, pemain akan lebih berhati dalam menentukan jawaban disetiap pertanyaan yang dimunculkan oleh sistem

Pelaksanaan penelitian ini dilakukan pada masa pandemic COVID-19 sehingga mengalami beberapa kendala, kendala tersebut yaitu serius game yang dikembangkan belum bisa diterapkan dalam pembelajaran dikelas secara langsung karena pada masa pandemi pembelajaran tatap muka ditiadakan dan dilaksanaka secara daring. Hal ini menyebabkan sulitnya pendistribusian game ke masing masing siswa, mengingat siswa SD sebagian besar belum memiliki laptop atau Personal Computer (PC). Untuk mengatasi kendala tersebut, peneliti hanya mengujicobakan game terhadap 4 siswa kelas 4 SD dengan tetap menerapkan protocol 
kesehatan. Kendala lain yang dialami peneliti adalah belum bisa menyelesaikan keempat tahapan pengembangan 4D, yaitu belum sampai tahap Disseminate. Kendala ini dialami karena keterbatasan waktu dan kemampuan yang dimiliki oleh peneliti.

\section{KESIMPULAN}

Serious game yang dikembangkan dalam penelitian ini berjudul "Math Snake". terdapat 2 bagian dalam game yaitu bagian KPK dan FPB. Game ini menggunakan metode inkuiri terbimbing, dimana seluruh aktifitas pemain diarahkan untuk berpikir secara sistematis dan logis untuk menemukan sendiri dan memahami materi pembelajaran yang terkandung didalamnya

Serious game yang dikembangkan telah dinilai oleh 2 orang ahli, yaitu ahli materi dan ahli media. Dari penilai tersebut diperoleh bahwa serious game yang dikembangkan dapat diterima oleh pengguna. Para ahli juga merekomendasikan serious game yang dikembangkan untuk digunakan dalam pembelajaran di kelas.

Ujicoba terbatas dilakukan terhadap 4 siswa kelas 4 sebagai pemain. Pemain tidak merasa kesulitan dalam memainkan game karena game menyediakan petunjuk permainan. Dari keempat pemain tersebut sangat antusias dalam memainkan Math Snake. Mereka termotivasi untuk memperoleh skor tertinggi.

Penelitian ini hanya dilakukan sampai pada tahap develop, bagi peneliti lain yang tertarik disarankan untuk mengembangkan penelitian sejenis sampai pada tahap disseminate. Selain itu, penelitian berikutnya diharapkan mampu membahas tentang bagaimana penerapan serious game ke dalam pembelajaran di kelas secara langsung.

\section{REFERENSI}

[1]. Rusman. Pembelajaran berbentuk Teknologi Informasi dan Komunikasi. Jakarta: Rajawali Pers, 2015.

[2] U.S. Hanifah, et al. "Peran Teknologi Dalam Pembelajaran Di Masa Pandemi Covid-19". Al-Mutharahah. 2020.

[3] A. Jihad. Pengembangan Kurikulum Matematika. Yogyakarta: Multi Pressindo, 2008.

[4] Sujoko. "Pemanfaatan Teknologi Informasi dan Komunikasi sebagai Media Pembelajaran di SMP Negeri 1 Geger" Jurnal Pengembangan Pendidikan. 2013. Tersedia pada: http://ejournal.umm.ac.id/index.php/jmkpp/a rticle/view/1511/1612 [diakses 19
November 2019]

[5] A.M. Fahrul. Pengertian Game Online dan Dampaknya. Jakarta: Media Anak, 2010.

[6] D. Hurd, E. Jenuings. "Standar-dized Educational Game Rating: Suggested Criteria", 2009. Tersedia pada: http://www.scribd.com/doc/16445410/Educ ational-Game-Ratings [diakses 20 November 2019]

[7] H. Trisna. Serious Game Jaringan Komputer Berbasis Simple Additive Weighting. Universitas Pendidikan Ganesha, 2016.

[8] H. Haryanto, W.S. Sari. "Serious Game Berbasis Konsep Open World Sebagai Sarana Belajar Mandiri dalam Pengenalan Bahasa Mandarin untuk Anak". Jurnal Techno.COM, 2012. Tersedia Pada http://publikasi.dinus.ac.id/index.php/techno c/article/view/1015/763 [diakses tanggal 11 november 2019].

[9] J. Hauge, B. Manjon. "Implications of learning analytics for serious game design", 2015. Tersedia pada: https://www.researchgate.net/publication/2 81872885 Implications of Learning Analy tics for Serious Game Design/link/568a5 17508aebccc4e19ece1/download [diakses tanggal 14 Mei 2020][10] Y.R. Qomarul, P. Bagus PMI. "Pengembangan Media Pembelajaran Game Edukasi Fisika Untuk Meningkatkan Motivasi Dan Prestasi Belajar Siswa Pada Materi Gerak-Gerak Lurus Beraturan, Berubah Beraturan, dan Jatuh Bebas". Jurnal Penelitan Pembelajaran, 2018.

[11] Mulyasa. Menjadi Guru Profesional Menciptakan Pembelajaran Kreatif dan Menyenangkan. Bandung: Remaja Rosdakarya, 2011.

[12] Hanafiah, S. Cucu. Konsep Strategi Pembelajaran. Bandung: Refika Aditama, 2009.

[13] Sanjaya. Strategi Pembelajaran Berorientasi Standar Proses Pendidikan. Jakarta: Prenanda Media Grup, 2006.

[14] I.M Suka. Pengembangan Game Edukasi Sebagai Media Pembelajaran Deret Bilangan di Sekolah Menengah Atas. Universitas Pendidikan Ganesha, 2018.

[15] I.N.A. Mahendra. Pengembangan Multimedia Berbentuk Game Edukasi pada Sub Pokok Bahasan Refleksi dan Translasi di Sekolah Menengah Pertama. Universitas Pendidikan Ganesha, 2016.

[16] Sugiyono. Metode Penelitian Kuantitatif Kualitatif dan R\&D. Bandung: Alfabeta, 2011. 
[17] J. Nesbit, K. Belfer, K. Leacock. Learning Object Review Instrument: User Manual, 2009.

[18] E. Widoyoko. Evaluasi Pembelajaran. Yogyakarta:

Program Pelajar, 2009.
[19.] H. Surjono. Multimedia Pembelajaran Interaktif: Konsep dan Pengembangan. Yogyakarta: UNY Press, 2017.

[20] D. Hardianto. "Penerapan Prinsip Desain Multimedia Untuk Pembelajaran". ICT Educ Peace", 2011. 